\title{
Ultrastructural features of Mimulus aurantiacus (Scrophulariaceae) pollen tubes in vivo
}

\author{
NURAN EKICI ${ }^{1}$, FERUZAN DANE $^{2}$ and GÖKSEL OLGUN ${ }^{2}$ \\ ${ }^{1}$ Department of Science Education, Faculty of Education, Trakya University, Ismail Hakki Tonguc Yerleskesi \\ 22030 Aysekadin, Edirne, Turkey \\ ${ }^{2}$ Department of Biology, Faculty of Science and Arts, Trakya University, Gullapoglu Yerleskesi, 22030, Edirne, Turkey \\ Manuscript received on September 2, 2007; accepted for publication on May 26, 2008; \\ presented by SERGIO VERJOVSKI-ALMEIDA
}

\begin{abstract}
The aim of this study is to give information on ultrastructure of in vivo pollen tubes of Mimulus aurantiacus which were collected from the Botanical Garden of the University of California at Berkeley. Materials were prepared according to electron microscopy methods and examined under Zeiss electron microscope. Four zones were examined in the pollen tubes of Mimulus aurantiacus. Apical zone: Mitochondria, smooth endoplasmic reticulum, rough endoplasmic reticulum, dictyosomes and secretory vesicles were observed. Subapical zone: This area contained abundant rough endoplasmic reticulum and occasionally some smooth endoplasmic reticulum. The polysomes, mitochondria, proplastids that contain starch, small vacuoles and a few lipid bodies were detected. Nuclear zone: Both generative and vegetative cell nuclei lie in this zone. The vegetative cell nucleus was large and long. Rough endoplasmic reticulum, mitochondria, ribosomes, dictyosomes, and amyloplasts that are rich of starch were observed. Vacuolation and plug formation zone: Cytoplasm of the tubes was full of large vacuoles. Few organelles such as mitochondria, dictyosome and rough endoplasmic reticulum were detected along their periphery.
\end{abstract}

Key words: in vivo, Mimulus, pollen tube, ultrastructure.

\section{INTRODUCTION}

Pollen, the male gametophyte of higher plants, is a biological system playing a central role in sexual plant reproduction (Cresti et al. 1992, Moscatelli and Cresti 2001). Interactions between pollen and the stigma surface initiate pollen germination, which involves an asymmetric extrusion of the pollen cytoplasm through a germination pore to initiate the outgrowth of a pollen tube. Various studies have been done about pollen tubes mostly concerning molecular (Graaf et al. 2005), cytochemical (Georgieva 1987), biochemical (Zonia et al. 2002) physiological; in vitro (Dane et al. 2004), in vivo (Unal 1986), semivivo (Bergamini Mulcahy and Mul-

Correspondence to: Nuran Ekici

E-mail: nuranekici@yahoo.com cahy 1985) and in situ (Dane 2000) aspects and pollenpistil interactions (Ferrari et al. 1985). The influences of various external factors; such as some chemicals (Kandasamy and Kristen 1987, Kim et al. 2003, Röderer and Reis 1988, Sawidisand and Reiss 1995) heat shock (Kandasamy and Kristen 1989), caffeine (Lancelle et al. 1997) and also pistil (Herrero and Arbeloa 1989) on pollen tube growth have been investigated. But ultrastructural studies about pollen tubes are very rare. Initial studies have been done in Petunia (Solanaceae) (Sassen 1964), (Cresti and Van Went 1976) and Lilium longiflorum (Liliaceae) (Rosen et al. 1964). Few reports have appeared in 1980s, concerning the fine structure of the pollen tubes in Lycopersicum peruvianum (Solanaceae) (Cresti et al. 1977), (Cresti et al. 1980), Prunus avium (Rosaceae) (Cresti et al. 1979), (Uwate and Lin 1980), 
Prunus sp. (Rosaceae) (Ciampolini et al. 1982), Nicotiana alata (Solanaceae) (Lancelle et al. 1987). In recent years, ultrastructural studies about pollen tubes have continued with Hosta ventricosa (Liliaceae) (Shi-Yi et al. 1992), Lilium longiflorum (Liliaceae) (Pierson et al. 1990), (Lancelle and Hepler 1992), Nicotiana tabacum (Solanaceae) (Yu and Russell 1993, Rutten 1993), Asclepias exaltata (Asclepiadaceae) (Sage and Williams 1995), Arabidopsis thaliana (Brassicaceae) (Lennon et al. 1998), and Conospermum species (Magnoliaceae) (Stone et al. 2004).

Those studies were generally on the ultrastructure of in vitro pollen tubes except the studies with Prunus avium (Cresti et al. 1979), (Uwate and Lin 1980). It is too hard to perform and to follow the development of in vivo pollen tubes, so these studies are very important and restricted. Therefore, the number of those studies should be increased.

Some electron microscope observations on pollen grains have been done in some members of subtribe Castilleiinae (Jensen et al. 1974) and in the genus Mimulus of subtribe Gratioleae Scrophulariaceae (Argue 1980). Olgun has done embryological researches on Digitalis sp. (Scrophulariaceae) with light microscope (Olgun 1979), (Yakar and Olgun 1984). She continued her studies with TEM such as ultrastructures of embryo sac (Olgun and Jensen 1987) and endothelium (Dane et al. 2007) in Penstemon gentianoides which belongs to the same family. This study can be regarded as the follow-up of those studies.

The ultrastructure of in vivo pollen tubes of Mimulus aurantiacus (Scrophulariaceae) which is naturally grown in North America, and possible similarities related to the ultrastructure of in vitro and in vivo pollen tubes in other angiosperms (Moscatelli and Cresti 2001) were emphasized in this study.

Ultrastructural studies were generally realized with the families Liliaceae, Solonaceae, Rosaceae and in recent years with some members of Asclepiadeceae, and Magnoliaceae. However, no studies have been found on ultrastuctural level with the pollen tubes of Scrophulariaceae family members neither in vivo nor in vitro. This will be the first ultrastructural study on in vivo pollen tubes of Mimulus aurantiacus and also in Scrophulariaceae family.

\section{MATERIALS AND METHODS}

Mimulus aurantiacus (Scrophulariaceae) flowers were collected from the Botanical Garden of the University of California at Berkeley. Gynoecia were removed from flowers and they were fixed in $4 \%$ glutaraldehyde in $0.1 \mathrm{M}$ cacodylate buffer $\mathrm{pH} 6.8$, for 2 hours. Then, the pollinated pistils were washed several times in buffer, fixed overnight with $2 \%$ buffered $\mathrm{OsO}_{4}$; dehydration was applied with gradually increasing aceton-propylenoxide series with staining in $70 \%$ acetone containing $1 \%$ uranyl nitrate overnight. The material was embedded in Spurr's medium. 0.5-1 m thick semi-thin sections were stained with methylene blue (1\%) using $0.02 \mathrm{M} \mathrm{NaOH}$ to control $\mathrm{pH}$ and observed by light microscopy. Thin sections were cut on a Porter-Blum ultramicrotome with a glass or diamond knife. Sections were stained on grids with lead citrate (Reynolds 1963) for one minute and observed by a Zeiss EM 9A electron microscope.

\section{RESULTS}

In this study, four zones were examined in vivo pollen tubes of Mimulus aurantiacus as similar in the previous studies.

\section{APICAL Zone}

The cytoplasm of that zone was rich of organelles. Many electron dense dictyosomes and spherical mitochondria were visible. Small vacuoles, abundant rough endoplasmic reticulum (RER), occasionally some smooth endoplasmic reticulum (SER) and electron dense lipid bodies were also seen (Fig. 1a). A well-developed RER (Fig. 1b) and dictyosomes were observed. Many vesicles budded out from the active dictyosomes were seen, in various sizes around cis and trans regions of dictyosomes, in the apical zone (Fig. 1c). Cell wall and cell membrane were also clearly visible in the electron micrographs of apical zone (Figs. 1a, b).

\section{SubAPICAL ZONE}

Proplastids containing starch granules, small vacuoles and spherical shaped mitochondria can be seen in this zone like apical zone (Fig. 2a). This zone also contained a few electron dense lipid bodies and abundant RER (Figs. 2a, b). The ribosomes were frequently aggregated 

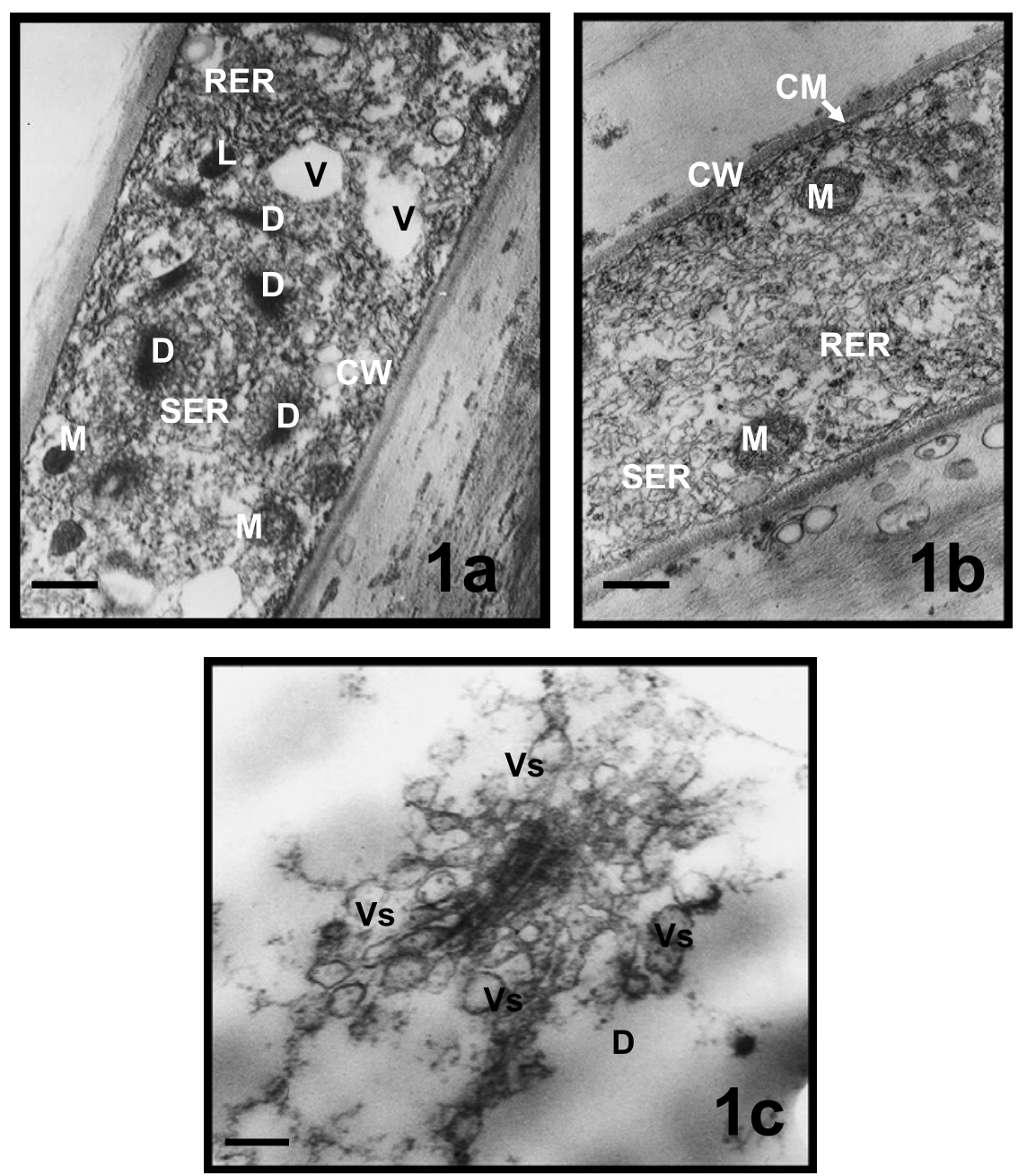

Fig. 1 - Apical zones of pollen tubes in Mimulus aurantiacus. a, b, views from apical zone; c, well-developed dictyosome in the apical zone. $\mathrm{a}, \mathrm{bar}=1 \mu \mathrm{m} ; \mathrm{b}, \mathrm{bar}=0,5 \mu \mathrm{m} ; \mathrm{c}, \mathrm{bar}=150 \mathrm{~nm}$. (CM, cell membrane; $\mathrm{CW}$, cell wall; $\mathrm{D}$, dictyosome; L, lipid; M, mitochondria; RER, rough endoplasmic reticulum; SER, smooth endoplasmic reticulum; Vs, vesicule).

as polysomes. Well-developed active dictyosomes and budding vesicles were also found in the subapical zone (Fig. 2c).

\section{NUCLEAR ZONE}

Vegetative and generative nuclei were located in this zone (Figs. 3, 4a, b). The vegetative cell nucleus was large and long. It contained one nucleolus and several weakly-stained chromatin aggregations. It was rich of euchromatin material. Vacuoles in different sizes, mitochondria and dictyosomes were observed around vegetative nucleus (Figs. 3a, b). There were 2, 3 amyloplasts containing starch grains and spherical shaped mitochondria around generative nucleus (Figs. 4a, b). Electron dense lipid bodies were seen near the amyloplast full of starch grains (Fig. 4b).

\section{Vacuolation and Plug Formation Zone}

Cytoplasm of the tubes was full of large and old vacuoles (Fig. 5a). Mitochondria, few ribosomes, polysomes and dictyosomes were seen along their periphery (Figs. 5a, b). There were also autophagic vacuoles exactly in the same size as others. They contained fibrillar materials (Fig. 5b). 

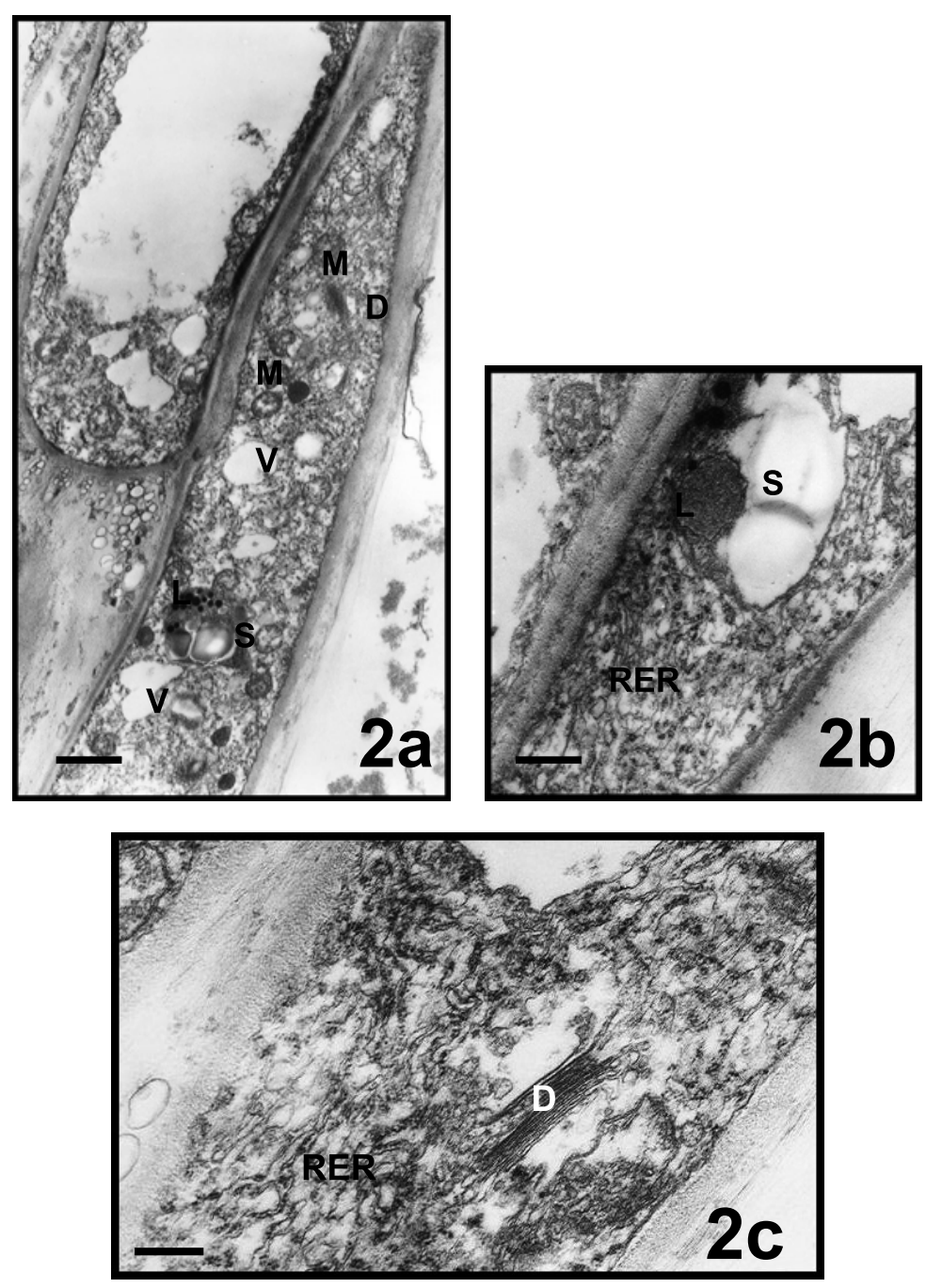

Fig. 2 - Subapical zones of pollen tubes in Mimulus aurantiacus. a, bar $=1,5 \mu \mathrm{m}$; $\mathrm{b}$, bar $=0,5 \mu \mathrm{m} ; \mathrm{c}$, bar $=0,2 \mu \mathrm{m} ;(\mathrm{D}$, dictyosome; L, lipid; $\mathrm{M}$, mitochondria; RER, rough endoplasmic reticulum; $\mathrm{S}$, starch; $\mathrm{V}$, vacuol).

\section{DISCUSSION}

The term "zonation" was introduced to describe the functional cytoplasmic distribution in the pollen tubes of Lycopersicum perivuanum (Cresti et al. 1977); in which four different areas were identified: (i) the apical zone, rich in SVs (Secretory Vesicles); (ii) the subapical area, containing organelles; (iii) the nuclear zone, comprising the MGU (Male Germ Unite); and (iv) the zone of vacuolization and callose plug formation (Moscatelli and Cresti 2001), (Bhojwani and Soh 2001). The presence of four zones was detected in the in vivo growing pollen tubes of Mimulus aurantiacus as reported by
Cresti et al. (1977), Ciampolini et al. (1982) in their in vitro and by Cresti et al. $(1979,1980)$, Uwate and Lin's (1980) in vivo studies. In general, the constitution of organelles in various zones in vitro and in vivo are quite similar as also seen in Lycopersicum (Cresti et al. 1977), (Cresti et al. 1980), in Malus (Speranza et al. 1982), in Prunus avium (Cresti et al. 1979), in cherry (Ciampolini et al. 1982), and in Conospermum (Stone et al. 2004).

It has been hypothesized that the apical zonation - applicable to most Angiosperm pollen tubes - is maintained by cytoplasmic movements within the growing tube and by the presence of a "capture mechanism" 

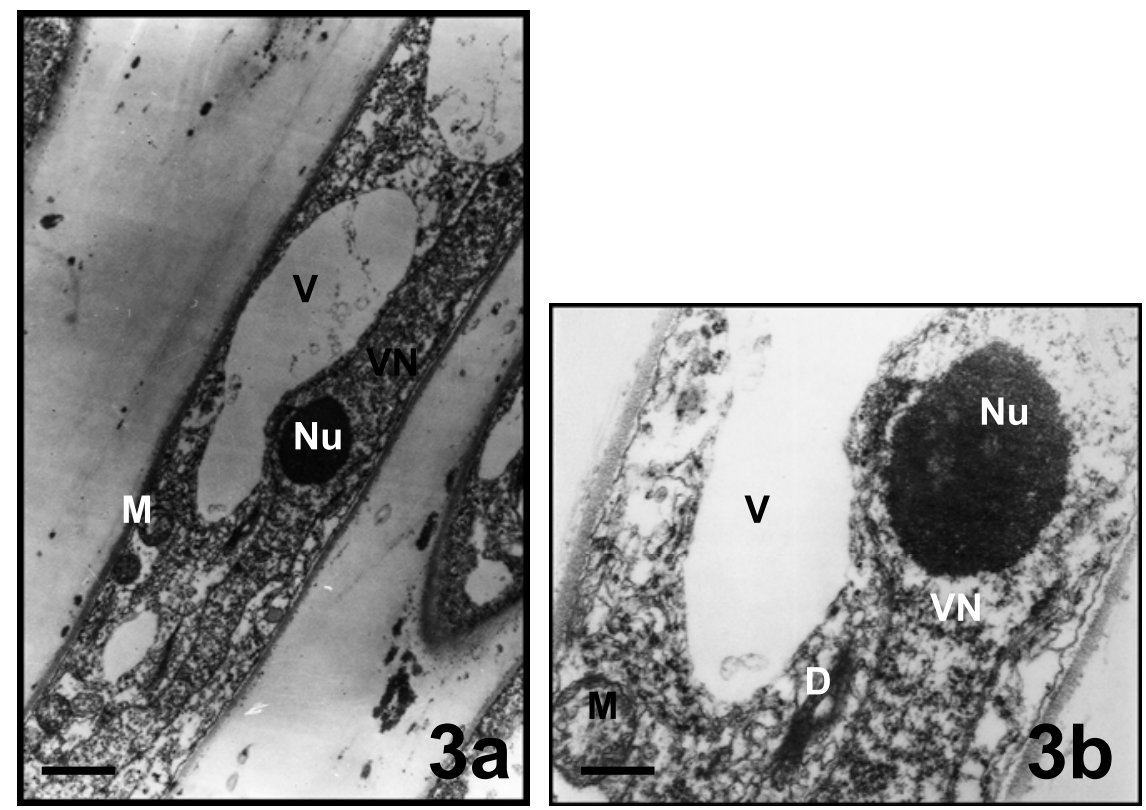

Fig. 3 - Nuclear zones (vegetative) of pollen tubes in Mimulus aurantiacus. a, bar $=1 \mu \mathrm{m} ; \mathrm{b}$, bar $=100 \mathrm{~nm}$. (D, dictyosome; M, mitochondria; Nu, nucleolus; V, vacuol VN, vegetative nucleus).
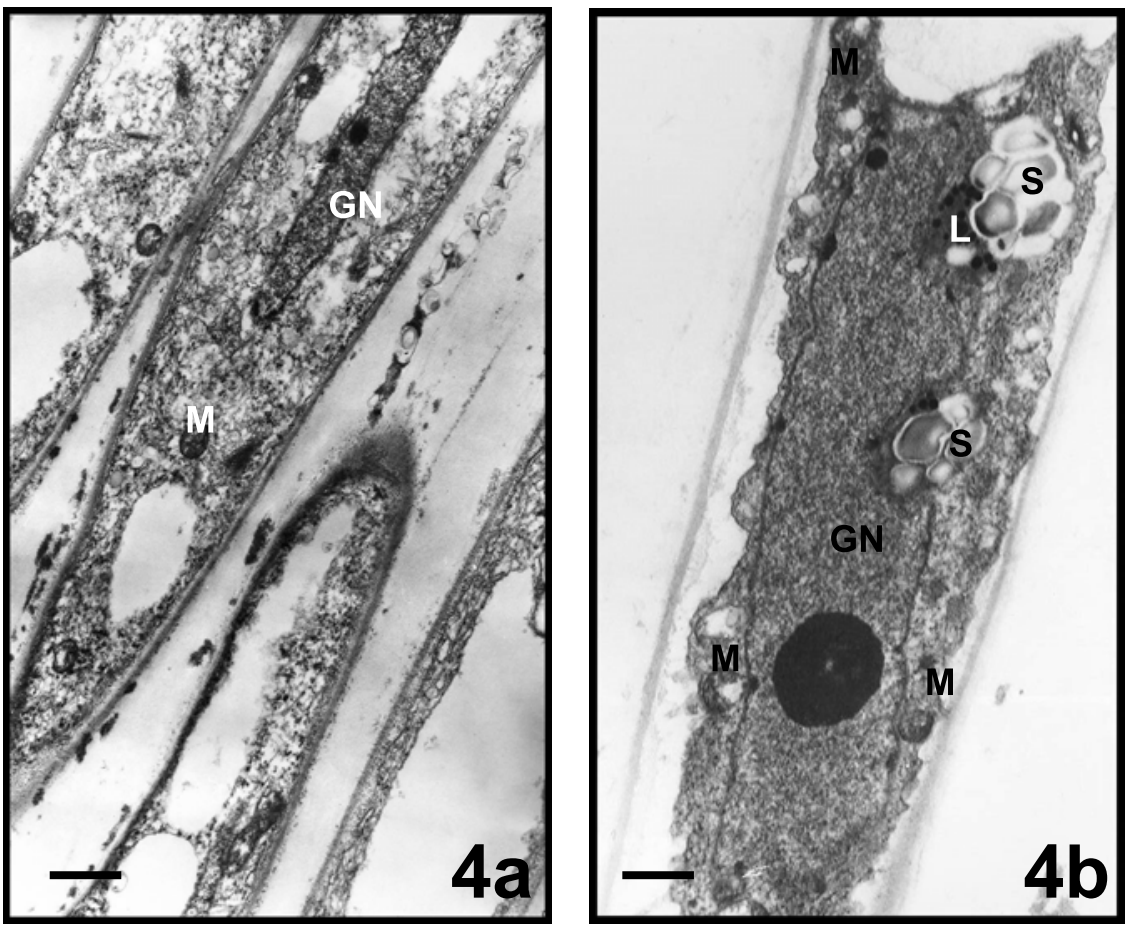

Fig. 4 - Nuclear zones (generative) of pollen tubes in Mimulus aurantiacus. a, bar $=1 \mu \mathrm{m} ; \mathrm{b}$, bar $=750 \mathrm{~nm}$. (GN, generative nucleus; L, lipid; M, mitochondria; S, starch). 

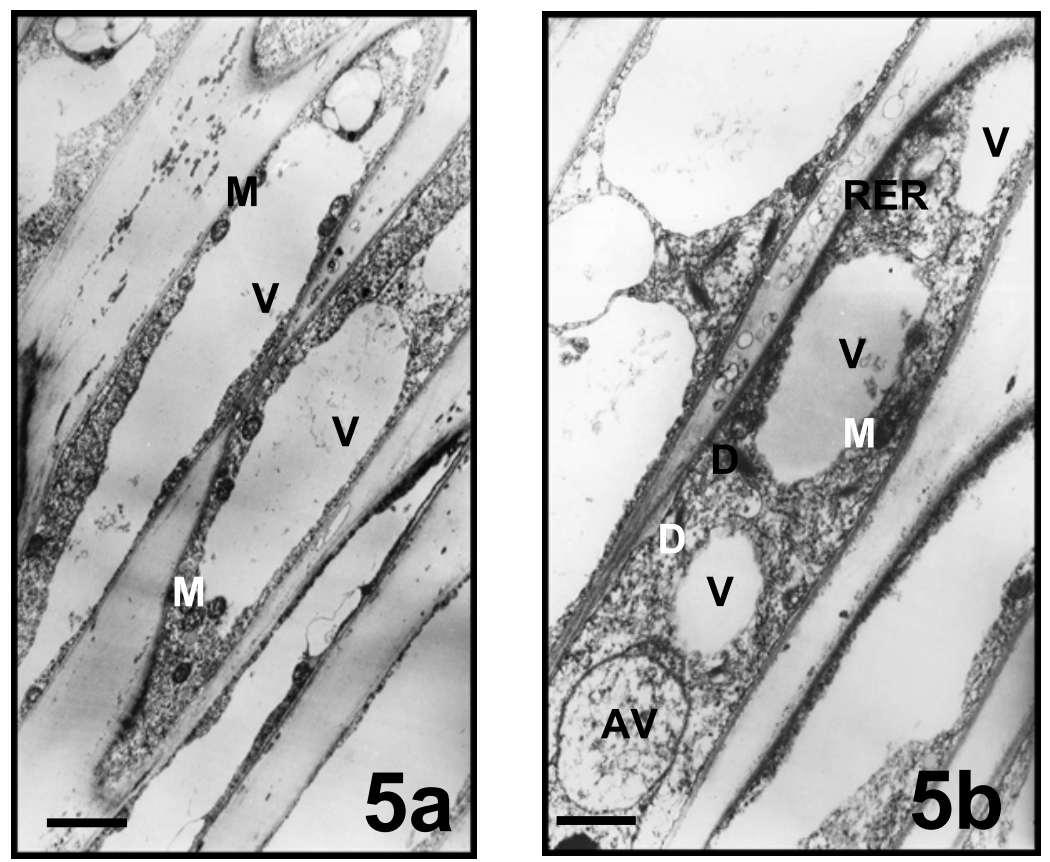

Fig. 5 - Vacuolation and plug formation zones of pollen tubes in Mimulus aurantiacus. a,b bar = 1, 5 $\mathrm{m}$; (AV, autophagic vacuole; $\mathrm{D}$, dictyosome; $\mathrm{M}$, mitochondria; RER, rough endoplasmic reticulum; $\mathrm{V}$, vacuol).

which concentrates Golgi-derived SVs at the tip (Heslop-Harrison and Heslop-Harrison 1989) where they fuse with the plasma membrane. This process of exocytosis provides wall polysaccharides and new plasma membrane for tube elongation (Moscatelli and Cresti 2001). Apical and subapical zones are active zones because they are rich of organelles such as: mitochondria, well-developed dictyosomes and lipid bodies. We also observed areas which would be designated as smooth and rough endoplasmic reticulum zones (Uwate and Lin 1980). Our micrographs showed small vesicles arising from the well-developed dictyosome cisternae. Besides playing a major role in the carbohydrate metabolism, dictyosomes have functioned as sorting and dispatching station for the ER products (Dupree and Sherrier 1998). According to Uwate and Lin (1980), these vesicles have been arisen from smooth endoplasmic reticulum cisternae, and rough endoplasmic reticulum circumscription of vacuoles. Lipid bodies were visible in various zones in our study. This was also mentioned by Uwate and Lin (1980).

Since pollen tubes go into the stigma and stylus, they need glycoproteins and glycolipids to build pollen tube wall. These molecules are synthesized in these welldeveloped dictyosomes. Amiloplasts detected in vivo growing pollen tubes of Mimulus auriaticus are less than in vitro ones of Prunus avium (Ciampolini et al. 1982). In vivo growing pollen tubes can absorb nutrients from the stylar tissue surrounding them. However, this may also occur in vitro studies due to high concentration of sucrose used in culture mediums.

Vacuolization zone exhibits autolysis or any other symptoms of degradation in pollen tubes of M. auraticus in vivo because this zone contains a lot of autophagic vacuoles in various sizes. Ciampolini et al. (1982) have specially mentioned the origin, ultrastructure and the role of secretory vesicles. These vesicles are generated by the dictyosomes, and seen in all zones of the pollen tubes. The older and larger vesicles are more visible in the vacuolization zone than in other zones. This is similar to the smaller vesicles in the apical zone due to participation in the pollen wall construction. Our in vivo electron micrographs of Mimulus aurantiacus pollen tubes also exhibit autophagic vacuoles. They have also been observed in pollen tubes of Lycopersicum peruvianum in vitro (Cresti et al. 1977). 
According to Cresti and Van Went (1976), there are two ways of callose deposition in Petunia pollen tubes growing in the style. The first one is callose deposition outside the plasma membrane; the second one is callose deposition within the cytoplasm as distinct callose grains, leading to the formation of callose plugs. Both pollen tube elongation and organelle distribution must be highly coordinated, so that pollen tube growth makes the oldest part of the vegetative cytoplasm move forward, and it becomes isolated by callose plug formation. The mechanism of growth in pollen tubes as well as in other cell types, requires the integrity of the secretory system, namely ER and Golgi apparatus. The secretory system involves the secretion of protein and polysaccharide components. In this study, the elements of RER, SER and Golgi apparatus dispersed through the pollen tube of Mimulus aurantiacus.

In conclusion, the ultrastructure of zonation in pollen tubes of Mimulus aurantiacus in vivo had similarities with the ultrastructure of in vivo pollen tubes in Prunus avium (Cresti et al.1979, Uwate and Lin 1980). In addition, it was seen that callose deposition occurred within the cytoplasm of pollen tubes in Mimulus aurantiacus.

\section{RESUMO}

O objetivo deste estudo é informar sobre a ultraestrutura de tubos de pólen de Mimulus aurantiacus in vivo coletados no "Botanical Garden" da Universidade da Califórnia em Berkeley. O material foi preparado de acordo com os métodos de microscopia eletrônica e examinado em microscópio eletrônico Zeiss. Quatro zonas dos tubos de pólen de Mimulus aurantiacus foram examinadas. Zona apical: foram observados mitocôndrias, retículo endoplasmático liso; retículo endoplasmático rugoso, dictiossomos e vesículas secretoras. Zona subapical: esta área continha retículo endoplasmático rugoso em abundância e, ocasionalmente, algum retículo endoplasmático liso. Foram detectados polissomos, mitocôndrias, proplastídeos que contêm amido, pequenos vacúolos e alguns corpos lipídicos. Zona nuclear: nesta área, existem tanto núcleos de células geradoras como vegetativas. O núcleo de célula vegetativa é grande e longo. Foram observados retículo endoplasmático rugoso, mitocôndria, ribossomos, dictiossomos e amiloplastos ricos em amido. Zona de vacuolização e de

formação de "plug": o citoplasma dos tubos estava cheio de grandes vacúolos. Algumas organelas como mitocôndria, dictiossomo e retículo endoplasmático rugoso foram detectadas em toda a periferia desta área.

Palavras-chave: in vivo, Mimulus, tubo de pólen, ultraestrutura.

\section{REFERENCES}

ARgue CL. 1980. Pollen morphology in genus Mimulus (Scrophulariaceae) and its taxonomic significance. Amer J Bot 67: 68-87.

Bergamini Mulcahy G And Mulcahy DL. 1985. Ovarian influence on pollen tube growth, as indicated by the semivivo technique. Amer J Bot 72: 1078-1080.

BhOJWANi SS AND SOH WY. 2001. Current trends in the embryology of angiosperms. Kluwer Academic Publishers: Dordrecht, The Netherlands, p. 33-65.

Ciampolini F, CResti M and Kapil RN. 1982. Germination of cherry pollen grains in vitro. An Ultrastructural Study. Pyhtomorphology 32: 364-373.

Cresti M And van Went JL. 1976. Callose deposition and plug formation in Petunia pollen tubes in situ. Planta 133: $35-40$.

Cresti M, Pacini E, Ciampolini F and Sarfatti G. 1977. Germination and early tube development in vitro of Lycopersicum peruvianum pollen: ultrastructural features. Planta 136: 239-247.

Cresti M, Ciampolini F, Pacini E, Sarfatti G and DONINI B. 1979. Ultrastructural features of Prunus avium L. pollen tubes in vivo. I. The compatible pollen tube. Caryologia 32: 433-440.

Cresti M, Ciampolini F and Sarfatti G. 1980. Ultrastructural investigations on Lycopersicum peruvianum pollen activation and pollen tube organization after selfand cross-pollination. Planta 150: 211-217.

CRESTi M, BlackMore S AND VAN Went JL. 1992. Atlas of sexual plant reproduction in flowering plants, SpringerVerlag, Berlin. 75 p.

DANE F. 2000. In situ germination of pollen tetrads in Periploca greaceae L. (Periplocaceae). Turk J Biol Tubitak 24: 337-343.

Dane F, Olgun G and Dalgic O. 2004. In vitro pollen germination of some plant species in basic culture medium. J Cell Mol Biol (Halic Univ. Press, Turkey) 3: 71-76.

DANE F, Olgun G AND EKICI N. 2007. Ultrastructure of endothelium in ovules of Penstemon gentianoides Poir. (Scrophulariaceae) at mature embryo sac phase. Acta Biol Hung 58: 225-233. 
DUPREE P AND SHERRIER DJ. 1998. The plant Golgi apparatus. Biochem Biophys Acta 1404: 259-270.

Ferrari TE, Best V, More TA, Comstock P, MuHamMAD A AND WALLACE DH. 1985. Intercellular adhesions in the pollen-stigma system: Pollen capture, grain binding, and tube attachments. Amer J Bot 72: 14661474.

GEORGIEVA ID. 1987. Cytochemical investigation of pollen and pollen tubes after $\gamma$-irradiation: II. Effect of the irradiation on quinine formation. Phytomorphology 37(2-3): 159-163.

Graaf BHJ, Cheung AY, Andreyeva T, Levasseur K, KiEliszeXSKi M AND WU H. 2005. Rab11 GTPaseregulated membrane trafficking is crucial for tip-focused pollen tube growth in tobacco. Plant Cell 17: 2564-2579.

Herrero M ANd ArbeloA A. 1989. Influence of the pistil on pollen tube kinetics in peach (Prunus persica) Amer J Bot 76: 1441-1447.

Heslop-HARrison J AND Heslop-HARRison Y. 1989. Actomyosin and movement in the angiosperm pollen tube: An interpretation of some recent results. Sex Plant Reprod 2: 199-207.

Jensen WA, Ashton M AND HeCKARd LR. 1974. Ultrastructural studies of the pollen of subtribe Castilleiinae, family Scrophulariaceae. Bot Gaz 135: 210-218.

KAndASAMY MK AND KRISTEN U. 1987. Pentachlorophenol affects mitochondria and induces formation of golgi apparatus-endoplasmic reticulum hybrids in tobacco pollen tubes. Protoplasma 141(2-3): 112-120.

KANDASAMY MK AND KRISTEN U. 1989. Ultrastructural responses of tobacco pollen tubes to heat shock. Protoplasma 153(1-2): 104-110.

Kim S, Mollet JC, Dong J, Zhang K, Park SY And LORD EM. 2003. Chemocyanin, a small basic protein from the lily stigma, induces pollen tube chemotropism. Plant Biol 100: 16125-16130.

LANCELlE SA AND HEPLER PK. 1992. Ultrastructure of freeze-substituted pollen tubes of Lilium longiflorum. Protoplasma 167(3-4): 215-230.

LANCElle SA, CResti M AND HePler PK. 1987. Ultrastructure of the cytoskeleton in freeze-substituted pollen tubes of Nicotiana alata. Protoplasma 140(2-3): 141-150.

LANCElle SA, CResti M ANd HePler PK. 1997. Growth inhibition and recovery in freeze-substituted Lilium longiflorum pollen tubes: structural effects of caffeine. Protoplasma 196(1-2): 21-33.
LENNON KA, Roy S, HePLER PK AND LORD EM. 1998. The structure of the transmitting tissue of Arabidopsis thaliana (L.) and the path of pollen tube growth. Sex Plant Reprod 11: 49-59.

Moscatelli A And Cresti M. 2001. Pollen germination and pollen tube growth. In: BOJWANI SS AND SOH WY (Eds.), Current trends in the embryology of angiosperms, Kluwer Academic Publishers: Dordrecht, The Netherlands, p. 33-65.

Olgun G. 1979. Comparative investigations on the karyology and embryology (Embryo sac and endosperm development) of Digitalis viridiflora Lindl. and Digitalis lutea L. Istanbul Univ. J Sci Fac B Series 44: 1-22.

Olgun G AND JENSEN JA. 1987. The ultrastructure of the egg apparatus and central cell of Penstemon gentianoides Poir. Before fertilization (Scrophulariaceae). Istanbul Univ Sci Fac J Series B 52: 35-45.

Pierson ES, Lichtscheidl IL AND DERKsen J. 1990. Structure and behaviour of organelles in living pollen tubes of Lilium longiflorum. J Exp Bot 41: 1461-1468.

REYNOLDS ES. 1963. The use of lead citrate of high $\mathrm{pH}$ as an electron-opaque stain in electron microscopy. J Cell Biol 17: 208-212.

Rosen WG, Gawlick SR, Dashek WV and SiegesMUND KA. 1964. Fine structure and cytochemistry of Lilium pollen tubes. Amer J Bot 51: 61-74.

RÖDERER G AND REIS HD. 1988. Different effects of inorganic and triethyl lead on growth and ultrastructure of lily pollen tubes. Protoplasma 144(2-3): 101-109.

RUtTEN ALM. 1993. Organelle distribution and cytoskeleton in the cytoplasm of tobacco pollen tube. Ph.D. Thesis. Chap. 6. University of Nijmegen. The Netherlands.

SAGE TL AND Williams EG. 1995. Structure, ultrastructure, and histochemistry of the pollen tube pathway in the milkweed Asclepias exaltata L. Sex Plant Reprod 8(5): 257-265.

SASSEN MMA. 1964. Fine structure of Petunia pollen grain and pollen tube. Acta Bot Neerl 13: 174-181.

SAWIDISAND T AND REISS HD. 1995. Effects of heavy metals on pollen tube growth and ultrastructure. Protoplasma 185(3-4): 113-122.

SHI-Yi H, CHUN-Gui L AND CHENG Z. 1992. Ultrastructure of microfilaments in pollen and pollen tubes of Hosta ventricosa $(=H$. coerulea). Zhíwùxué Bào 34: 8-14.

Speranza A, CAlzoni GL, Cresti M And Ciampolini F. 1982. Effects of gamma irradiation on in vitro germi- 
nation and ultrastructure of apple pollen. Env Exp Bot 22: 339-347.

Stone LM, Seaton KA, Kuo J And McComb JA. 2004. Fast Pollen Tube Growth in Conospermum Species. Ann Bot 93: 369-378.

UNAL M. 1986. A comperative cytological study on compatible and in-compatible pollen tubes of Petunia hybrida. Istanbul Univ Sci Fac J Series B 51:1-12.

UWATE WJ AND LIN J. 1980. Cytological zonation of Prunus avium L. pollen tubes in vivo. J Ultrastruct Res 71: 173-184.
YAKAR N AND OLGUN G. 1984. Comparative investigations on the megasporogenesis and embryo sac development of Digitalis divisiana Heyw. and Digitalis ambigua. Murr J Nat Sci 8(3): 1-22.

YU HS AND RUSSELl SD. 1993. Three-dimensional ultrastructure of generative cell mitosis in the pollen tube of Nicotiana tabacum. Eur J Cell Biol 61: 338-348.

Zonia L, Cordeiro S, Tupy J AND FeiJo JA. 2002. Oscillatory chloride efflux at the pollen tube apex has a role in growth and cell volume regulation and is targeted by inositol 3,4,5,6-tetrakisphosphate. Plant Cell 14: 22332249. 